\title{
Effect of depth and age on leachate characteristics of Achan Landfill, Srinagar, Jammu and Kashmir, India.
}

\author{
${ }^{1}$ S. Fatima, ${ }^{2}$ S. K. Rafiq*, ${ }^{3}$ A.Hai \\ ${ }^{1,2}$ P.G Department of Environment S.P. Post Graduate College, Srinagar, 190001, Jammu \& Kashmir, India. \\ ${ }^{3}$ Hydrobiology Research Laboratory, S. P. Post Graduate College, Srinagar, 190001, Jammu \& Kashmir, India
}

\begin{abstract}
Periodic monitoring of leachate quality at variable depths(0.3,2.0,5.0 and $60 \mathrm{~m})$ at seven different sites was carried out for a period of two years at Achan Landfill site operational from last twenty years. The leachates were monitored for changes in $\mathrm{pH}, \mathrm{EC}, \mathrm{TDS}, \mathrm{TSS}, \mathrm{HCO}_{3}^{-}$, chloride, $\mathrm{Ca}^{2+}, \mathrm{Mg}^{2+}, \mathrm{Na}^{+}, \mathrm{K}^{+}$, phosphorus, nitrogen, $\mathrm{BOD}, \mathrm{COD}$, and heavy metals $(\mathrm{Cu}, \mathrm{Cr}, \mathrm{Ni}, \mathrm{Zn}, \mathrm{Pb}, \mathrm{Cd})$. Comparing the results the concentration at $2 \mathrm{~m}$ depth varied significantly among the sites $(p<0.5)$. Parameters like $\mathrm{NO}_{2}, \mathrm{NO}_{3}, \mathrm{NH}_{4}$ and $T K N$ showed positive correlation within first three depths i,e $0.3 \mathrm{~m}$ to $5 \mathrm{~m}$ while as other parameters like $\mathrm{pH}, \mathrm{EC}$, $T D S$, , $\mathrm{HCO}_{3}{ }^{-}$, chloride, $\mathrm{Ca}^{2+}, \mathrm{Mg}^{2+}, \mathrm{Na}^{+}, \mathrm{K}^{+}, \mathrm{BOD}, \mathrm{COD}$, show negative correlation with respect to depth at $2 \mathrm{~m}$ and other depths except for surface leachate collected at $0.3 \mathrm{~m}$. Regarding the stabilization of the land fill two important indicating parameters viz, $B O D_{5} / \mathrm{NH}_{4}$ and $B O D_{5} / C O D$ ranged between 0.002 and 1 and 0.03 to 0.29 which implies that the landfill has attained stabilization. Results revealed that the stabilization of leachate constituents (Inorganic and Organic) correlates well with the age of the dumping site because of well developed methanogenic conditions
\end{abstract}

Key Words: leachate, landfill,BOD,COD and methanogenic

\section{Introduction}

The oldest and most widely used method for ultimate disposing of solid waste is Landfilling. It is the most common method for municipal and industrial solid waste disposal (Tchobanoglous et al-1997). Landfills generate significant amount of a highly contaminated liquid called leachate. The composition of the leachate varies widely dependably on waste type and waste age (Christensen et al-1994). Leachate from young sites is much more of a contaminated nature than that of mature landfill. $\mathrm{pH}$ moves from slightly acid to neutral, $\mathrm{BOD}_{5}$ to COD ratio and $\mathrm{SO}_{4}$ to $\mathrm{Cl}$ ratio decreases with the age of landfill (Chian and DeWalle, 1997). Various methods to evaluate the leachate quality variations were reported by EL-Fadel et-al 2002. A technique developed by Kumar \& Alappat (2003), quantifies the landfill leachate pollution in terms of leachate pollution index (LPI).A higher value than 7.5 indicates a polluting leachate. LPI is also useful to monitor the leachate trends over the life time of the site.

The paper is aimed to study the leachate characteristic and stabilization at various depths and its impact on ground water quality.

\section{Study Area}

\section{Material And Methods}

The present study was carried out at municipal solid waste landfill at Achan, Srinagar lying between $34^{\circ} 09^{\wedge} \mathrm{N}$ Latitude and $74^{\circ} 79^{-} \mathrm{E}$ Longitude that is being used for last twenty (20)years. Table.1. presents the salient features of the dump site. The landfill in its present state is hazardous to its surroundings because it is neither insulated from the bottom by any liner nor demarcated from the surrounding by any concrete barrier. The runoff from the landfill contributes to the pollution of nearby fresh water Anchar Lake.

\section{Leach ate Characterization}

The samples were collected on monthly basis at variable depth of $0.3 \mathrm{~m}, 2 \mathrm{~m}, 5 \mathrm{~m}$, and $60 \mathrm{~m}$ from seven different sites of landfill for a period of 2 years in clean bottles with proper labeling as detailed by Elasakku et al, 2006. Leachate characteristics such as pH, TDS, TSS, EC, $\mathrm{HCO}_{3}^{-}, \mathrm{Cl}^{-}, \mathrm{Na}^{+}, \mathrm{K}^{+}, \mathrm{Ca}^{2+}, \mathrm{Mg}^{2+}$, $\mathrm{NH}_{4}{ }^{+}, \mathrm{NO}^{3-}, \mathrm{BOD}_{5}, \mathrm{COD}$, and heavy metals $(\mathrm{Cu}, \mathrm{Cr}, \mathrm{Ni}, \mathrm{Zn}, \mathrm{Pb}, \mathrm{Cd})$ were determined as per standard methods of APHA, 1998.

The data obtained were subjected to stastical analysis employing standard stastical procedures. 
Effect of depth and age on leachate characteristics of Achan Landfill, Srinagar, Jammu and Kashmir,

Table 1: Site Characteristics of Achan, Saidpora.

\begin{tabular}{|l|l|}
\hline Total site area (ha) & 13.03 ha \\
\hline Waste filled area (ha) & Approx. 10.8 ha \\
\hline Disposal quantity (MT/d) & Approx. 600 \\
\hline Ownership & $\begin{array}{l}\text { Srinagar Municipal } \\
\text { Corporation }\end{array}$ \\
\hline Waste disposal method & $\begin{array}{l}\text { Open dumping and } \\
\text { leveling by bulldozer }\end{array}$ \\
\hline Average depth of waste dump (m) & Approx. 1.5 m \\
\hline Ground condition & Silty-clay soil \\
\hline Hydrology & $\begin{array}{l}\text { Water table at 7-8 feet } \\
\text { (max.) }\end{array}$ \\
\hline Age & 26 years \\
\hline
\end{tabular}

Source: Srinagar Municipal Corporation.

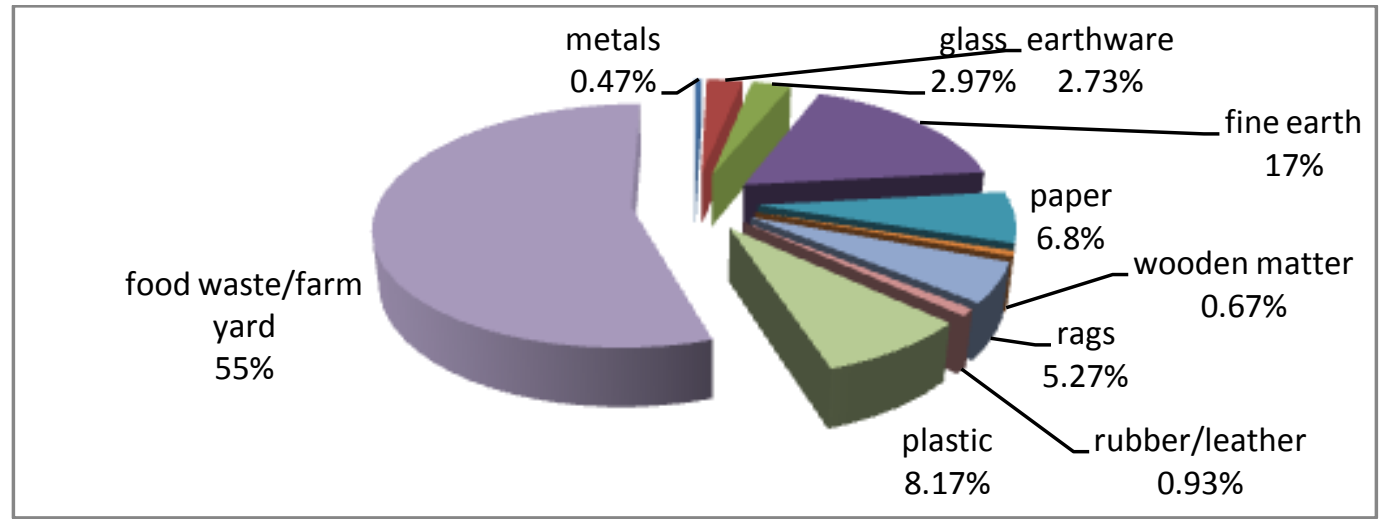

Source: Economic Reconstruction Agency, Srinagar,Jammu and Kashmir, 2010.

Fig.1.Average Physical composition of MSW of Srinagar City

\section{Results And Discussions}

The mean and \pm standard error for each analyte is given in Table 2-7. The graphical representation of the same data is shown in figure $2-7$.

Table 2. Physico-chemical characteristics of leachates at various depths.

\begin{tabular}{|c|c|c|c|c|}
\hline \multirow{2}{*}{ Parameters } & \multicolumn{4}{|c|}{ Depths } \\
\hline & $0.30 \mathrm{~m}$ & $2 \mathrm{~m}$ & $5 \mathrm{~m}$ & $60 \mathrm{~m}$ \\
\hline \multirow{2}{*}{ TDS mg/L } & 3301 & 3414 & 2457 & 1090 \\
\hline & +120 & +232 & \pm 156 & \pm 133 \\
\hline \multirow{2}{*}{ TSS mg/L } & 322 & 347 & 358 & 1639 \\
\hline & +17 & +24 & \pm 16 & +238 \\
\hline \multirow{2}{*}{$\mathrm{HCO}^{3-} \mathrm{mg} / \mathrm{L}$} & 2877 & 3574 & 1505 & 898 \\
\hline & +407 & +755 & +82 & +66 \\
\hline \multirow{2}{*}{ pH } & 6.78 & $\overline{7.62}$ & $\overline{6.94}$ & $\overline{7.22}$ \\
\hline & \pm 0.22 & +0.15 & +0.09 & \pm 0.06 \\
\hline \multirow{2}{*}{ EC } & 4480 & 4862 & 3361 & 819 \\
\hline & +221 & +356 & +278 & +88 \\
\hline
\end{tabular}

\pm represents standard error 


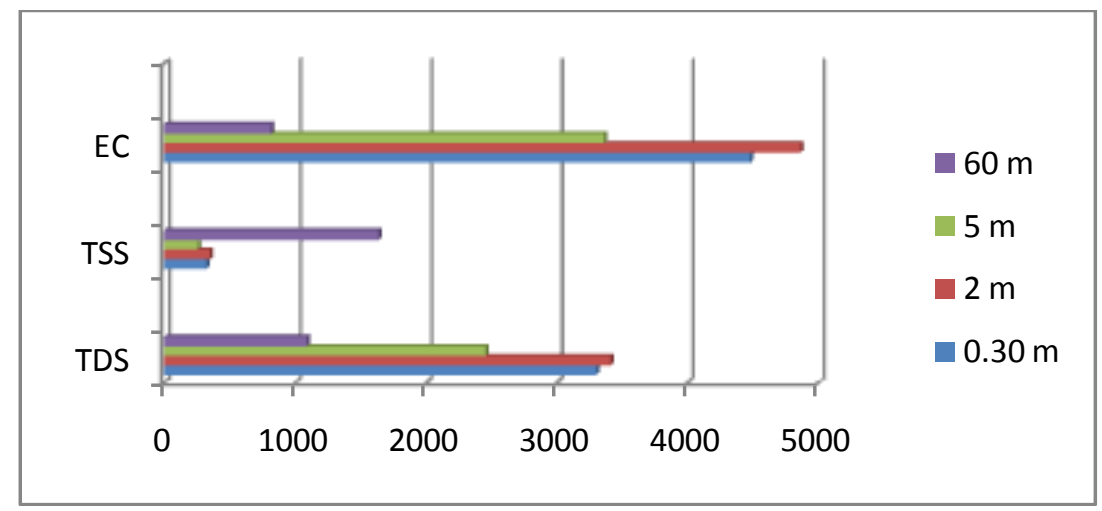

Fig.2. Physico-chemical characteristics of leachates at various depths

\section{TDS,TSS and BICARBONATES}

As evident from Table 2, fig. 2, the mean concentration of TDS decreases with increase in depth from values of $3414 \mathrm{mg} / \mathrm{l}$ at $2 \mathrm{~m}$ to $1089 \mathrm{mg} / \mathrm{l}$ at $60 \mathrm{~m}\left(\mathrm{r}=-0.94 ; \mathrm{r}^{2}=0.88\right)$. The mean values of TSS in contrast to TDS, increases with increase in depth with strong positive correlation $\left(r=0.99 ; r^{2}=0.98\right)$. The values ranged from $322 \mathrm{mg} / \mathrm{l}$ at $0.3 \mathrm{~m}$ to $1638 \mathrm{mg} / \mathrm{l}$ at $60 \mathrm{~m}(\mathrm{p}<0.05)$ as shown in Table 2 and Fig.2.

Both TSS \& TDS increases with increase in precipitation $\left(r=0.65 ; r^{2}=0.42\right.$ and $\left.r=0.92 ; r^{2}=0.85\right)$ as a result of percolation that leaches dissolved and suspended components from the waste through several physical and chemical reactions. These components can further provide adsorptive site for certain chemical and biological agents (Abbas et al., 2009 and Aluko et al., 2003). The decreasing trend of TDS at greater depths may be related to the increase in liquid portion of leachate that tends to accumulate at the base of landfill while losing the solute portion continuously through decomposition, interaction with soil components and distribution processes. Longer time is required for distribution of leached material to reach lower levels (Qasim and Chiang, 1994 and $\mathrm{Lu}$ et al, 1985).

Bicarbonates result from the action of $\mathrm{CO}_{2}$ upon basic materials in solid wastes (Shivahumar et al, 2004).During the study period the overall pattern of bicarbonates was similar to those of TDS, TSS, EC and some ionic pollutants with no significant difference within first 2 meters $(\mathrm{p}<0.05)$.

The mean values of $\mathrm{HCO}_{3}{ }^{-}$decrease with increase in depth $\left(\mathrm{r}=-0.75 ; \mathrm{r}^{2}=0.56\right)$ from about $3225 \mathrm{mg} / \mathrm{l}$ within first 2 meters to $897 \mathrm{mg} / \mathrm{l}$ at $60 \mathrm{~m}$. The mean value of bicarbonates concentration near surface was reduced by about $19.5 \%$ compared to concentration at $2 \mathrm{~m}$. The bicarbonates also showed direct relationship with precipitation with concentrations increasing with increase in precipitation $\left(r=0.94 ; r^{2}=0.88\right)$.A direct relation between alkalinity and precipitation and our observations are in agreement with the results obtained by Me Bean et al, 1995.

\section{pH and electrical conductivity}

The mean $\mathrm{pH}$ values at different depths did not show any significant variation. The mean values range from 6.78 at $0.3 \mathrm{~m}$ depth to 7.6 at $2 \mathrm{~m}$ depth. The $\mathrm{pH}$ near the surface is slightly acidic as compared to other depths. An acidic $\mathrm{pH}$ near the surface may be related to the to the oxidation of organic waste by aerobic bacterial (Shivakumar et al., 2004).These conditions are apparently less dominant at greater depths thus contributing to observed alkalinity. The coefficient of variation tends to decrease with increase in depth $(\mathrm{r}=$ $\left.0.70 ; r^{2}=0.49\right)$ indicating increase in stability conditions with increase in depth.

The mean values of conductance have decreased from about $4480 \mu \mathrm{Scm}^{-1}$ near surface $(0.3 \mathrm{~m})$ to 819 $\mu \mathrm{Scm}^{-1}$ at $60 \mathrm{~m}\left(\mathrm{r}=-0.95 ; \mathrm{r}^{2}=0.9\right)$. The significant differences were observed between the mean values of conductance and depths except within first $2 \mathrm{~m}$ as observed with TDS and TSS $(\mathrm{p}<0.05)$. The variation in the conductivity values are related to alterations in ion concentration at different depths.

Electrical conductivity also increases with increase in precipitation $\left(r=0.98 ; r^{2}=0.96\right)$ as in case of TDS and TSS. These results are in agreement with the results obtained by Karthikeyan et al (2007) who has recorded high conductivity values at the beginning of monsoon period which got reduced drastically due to dilution towards the end of monsoon period.

\section{Ionic Pollutants:}

Ionic pollutants like chloride, calcium, magnesium, sodium and potassium showed similar trends of decrease with increase in depth except for first two i,e $0.3 \mathrm{~m}$ and $2 \mathrm{~m}$ which showed increasing trend. The observed concentrations for all the ionic pollutants at $2 \mathrm{~m}$ depth are significantly higher than that at $0.3 \mathrm{~m}(\mathrm{p}<0.5)$ as shown in Table 3 and fig. 3 . The higher concentration of these ions at the base of waste bed i,e $2 \mathrm{~m}$ is in agreement with the findings of Qasim and Chaing et al,1994. 
Effect of depth and age on leachate characteristics of Achan Landfill, Srinagar, Jammu and Kashmir,

Table 3. Ionic pollutant concentration in leachate in $\mathrm{mg} / \mathrm{L}$.

\begin{tabular}{|c|c|c|c|c|}
\hline \multirow{2}{*}{ Parameters } & \multicolumn{4}{|c|}{ Depths } \\
\hline & $0.30 \mathrm{~m}$ & $2 \mathrm{~m}$ & $5 \mathrm{~m}$ & $60 \mathrm{~m}$ \\
\hline \multirow[b]{2}{*}{$\mathrm{Cl}^{-}$} & 624 & 1868 & 648 & 237 \\
\hline & +33 & +175 & +51 & +42 \\
\hline \multirow{2}{*}{$\mathrm{Ca}^{++}$} & $\overline{127}$ & 280 & $\overline{144}$ & 65 \\
\hline & +13 & +26 & +15 & +8 \\
\hline \multirow{2}{*}{$\mathbf{M g}^{++}$} & 286 & 515 & 346 & 129 \\
\hline & \pm 31 & \pm 37 & \pm 34 & \pm 13 \\
\hline \multirow{2}{*}{$\mathbf{N a}^{+}$} & 140 & 244 & $\overline{154}$ & 77 \\
\hline & \pm 10.62 & \pm 17.26 & +13.3 & +11.37 \\
\hline \multirow{2}{*}{$\mathbf{K}^{+}$} & 122 & 636 & 283 & 33 \\
\hline & +14 & +29 & +40 & +5 \\
\hline \multirow{2}{*}{$\mathbf{P O}^{4-}$} & $\overline{37.5}$ & $\overline{19.14}$ & $\overline{5.88}$ & $\overline{1.9}$ \\
\hline & +3.3 & \pm 1.9 & \pm 0.68 & \pm 0.45 \\
\hline
\end{tabular}

\pm represents standard error

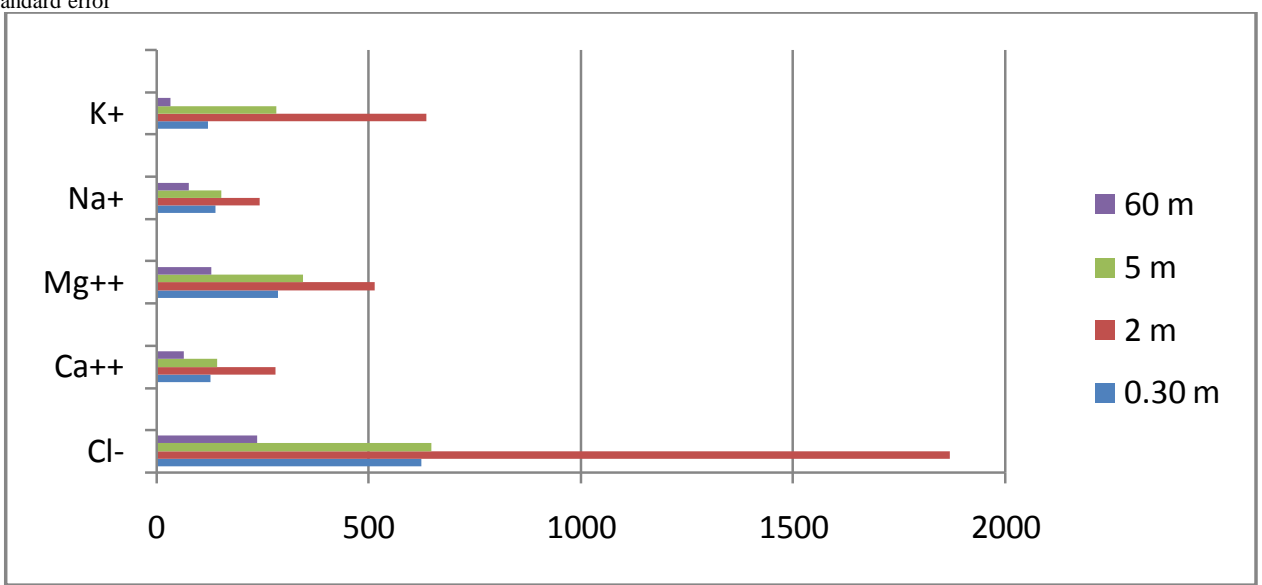

Fig.3.Ionic pollutant concentration in leachate in $\mathrm{mg} / \mathrm{L}$.

The observed chloride concentration of leachate are very high with mean concentration decreasing with increasing depth from $1868 \mathrm{mg} / \mathrm{l}$ at $2 \mathrm{~m}$ to $237 \mathrm{mg} / \mathrm{l}$ at $60 \mathrm{~m}$ depth $\left(\mathrm{r}=-0.73 ; \mathrm{r}^{2}=0.53\right)$. However, the mean values near the surface $(0.3 \mathrm{~m})$ were significantly reduced to about $67 \%$ than at $2 \mathrm{~m}$ depth. The coefficient of variation for the analyte also tends to increase with increase in depth. These results are in agreement with that of Chu et al (1994) and Komilis et al (1999).

Similar trends were observed for calcium and magnesium with concentrations of $65 \mathrm{mg} / \mathrm{l}$ at $60 \mathrm{~m}$ and $280 \mathrm{mg} / \mathrm{l}$ at $2 \mathrm{~m}\left(\mathrm{r}=-0.80 ; \mathrm{r}^{2}=0.65\right)$ for calcium and129 $\mathrm{mg} / \mathrm{l}$ at $60 \mathrm{~m}$ to $515 \mathrm{mg} / \mathrm{l}$ at $2 \mathrm{~m}$ for magnesium $(\mathrm{r}=$ $\left.0.092 ; \mathrm{r}^{2}=0.85\right)$. The concentration at the surface $(0.3 \mathrm{~m})$ show considerable reduction with those at $2 \mathrm{~m}$ for both calcium (55\%)and magnesium (44\%). The observed concentration of magnesium was always higher as compared to calcium. The result are in agreement with those of Robinson el al. (2007) and Stuart and Klink (1997) for landfills undergoing methanogenesis.

Like $\mathrm{Cl}^{-}, \mathrm{Ca}^{2}$, and $\mathrm{Mg}^{2+}$, sodium and potassium tends to increase with decrease in depth upto $2 \mathrm{~m}$ from about $77 \mathrm{mg} / \mathrm{l}$ at $60 \mathrm{~m}$ to $244 \mathrm{mg} / \mathrm{l}$ at $2 \mathrm{~m}\left(\mathrm{r}=-0.87 ; \mathrm{r}^{2}=0.75\right)$ for sodium and from about $333 \mathrm{mg} / \mathrm{l}$ at $60 \mathrm{~m}$ to about $636 \mathrm{mg} / \mathrm{l}$ at $2 \mathrm{~m}\left(\mathrm{r}=-0.84 ; \mathrm{r}^{2}=0.7\right)$ for potassium. The mean concentrations near the surface $(0.03 \mathrm{~m})$ are significantly lower $\left(43 \%\right.$ for $\mathrm{Na}^{+}$and about $81 \%$ for $\left.\mathrm{K}^{+}\right)$than the concentrations at $2 \mathrm{~m}$ depth $(\mathrm{p}<0.05)$. Alterations in concentrations of $\mathrm{Na}^{+}$and $\mathrm{K}^{+}$may be related to addition of fresh leachate as well as to the continuous washout due to precipitation. Similar observations are on record by Karthikeyan et al., (2007); Qasim and Chiang (1994) and Mor et al., (2006).

Low concentrations of ortho-phosphates are indicator about the degree of an-aerobics that is predominant in the landfill (Karthikeyan et al., (2007). The mean concentrations of $\mathrm{PO}_{4}{ }^{-}$tend to decrease with increase in depth from about $2 \mathrm{mg} / \mathrm{l}$ at $60 \mathrm{~m}$ to about $38 \mathrm{mg} / \mathrm{l}$ at $0.03 \mathrm{~m}$. The change is highly correlated over $0.03 \mathrm{~m}$ to $5 \mathrm{~m}\left(\mathrm{r}=-0.97 ; \mathrm{r}^{2}=0.14\right)$ compared to $0.3 \mathrm{~m}$ to $60 \mathrm{~m}\left(\mathrm{r}=-0.64 ; \mathrm{r}^{2}=0.41\right)$. The coefficient of variation for the analyte tends to increase with increase in depth $\left(r=0.99 ; r^{2}=0.99\right)$ with significant difference in concentrations between the depths $(\mathrm{p}<0.05)$. 
Effect of depth and age on leachate characteristics of Achan Landfill, Srinagar, Jammu and Kashmir,

Table 4. Nitrogenous pollutant concentration in leachate in mg/L.

\begin{tabular}{|c|c|c|c|c|}
\hline \multirow{2}{*}{ Parameters } & \multicolumn{4}{|c|}{ Depths } \\
\hline & $0.30 \mathrm{~m}$ & $2 \mathrm{~m}$ & $5 \mathrm{~m}$ & $60 \mathrm{~m}$ \\
\hline \multirow{2}{*}{$\mathrm{NO}_{3}{ }^{-}$} & 6.50 & 11.48 & 28.23 & 3.10 \\
\hline & +0.88 & \pm 0.7 & \pm 2.6 & \pm 0.3 \\
\hline \multirow{2}{*}{$\mathrm{NO}_{2}$} & 6.68 & 12.45 & 26.15 & 3.0 \\
\hline & \pm 0.92 & \pm 0.99 & \pm 1.75 & \pm 0.23 \\
\hline \multirow{2}{*}{$\mathbf{N H}_{4}$} & 584 & 183 & 698 & 687 \\
\hline & +55 & \pm 17 & \pm 26 & \pm 30 \\
\hline TKN & $\begin{array}{c}700 \\
+631\end{array}$ & $\begin{array}{r}211 \\
+2930\end{array}$ & $\begin{array}{r}\mathbf{8 2 3} \\
+675\end{array}$ & $\begin{array}{c}805 \\
+620\end{array}$ \\
\hline
\end{tabular}

\pm represents standard error

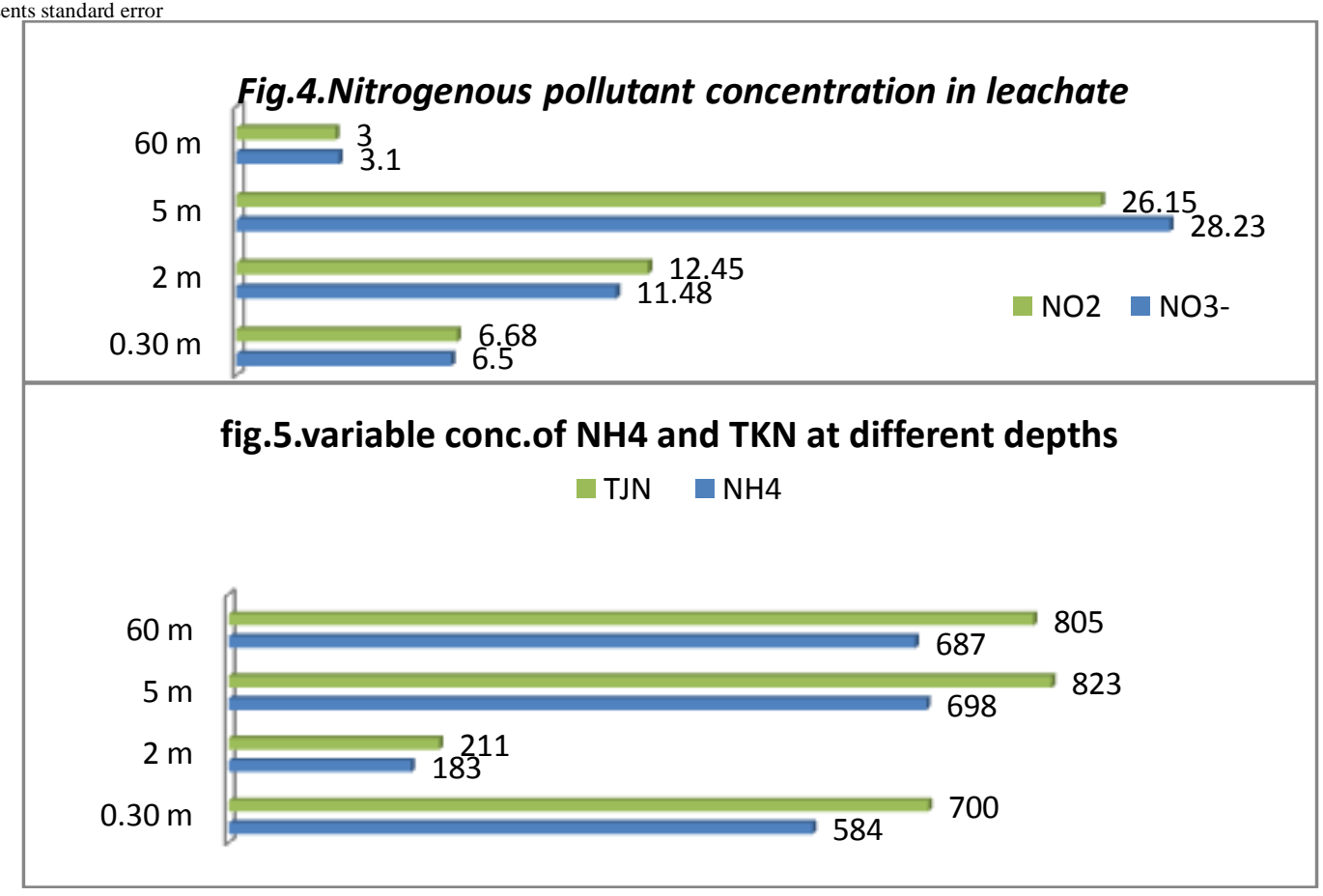

\section{Nitrogenous pollutants :}

The mean concentrations of $\mathrm{NO}_{3}-\mathrm{N}$ show linear decrease with decrease in depth from $28.23 \mathrm{mg} / \mathrm{l}$ at $5 \mathrm{~m}$ to $6.5 \mathrm{mg} / 1$ at $0.3 \mathrm{~m}\left(\mathrm{r}=0.99 ; \mathrm{r}^{2}=0.98\right)$ as illustrated in Table 4 ,fig. 4 and 5 .. However, the concentrations at $60 \mathrm{~m}$ are nearly $50 \%$ of the concentration formed near the surface. The mean concentrations vary significantly between the depths $(\mathrm{p}<0.05)$.

The increasing trend of nitrate nitrogen concentration, with increasing depth upto $5 \mathrm{~m}$ may be attributed to the high solubility and good leaching potential of nitrates. Concentrations of $\mathrm{NO}_{3}-\mathrm{N}$ are significantly lower than that of $\mathrm{NH}_{3}-\mathrm{N}$, which is in agreement with the observation of Mc Bean et al (1995) and Karthikeyan (2007). This may be attributed to the reducing environment prevailing in the landfill.

The mean concentrations of ammonical nitrogen do not show any correlation with change in depth. The recorded concentrations at $0.03,2.5$ and $60 \mathrm{~m}$ are of the order of 584,183,698 and $687 \mathrm{mg} / \mathrm{l}$. Low concentrations of ammonical nitrogen at $2 \mathrm{~m}$ may be attributed to its low retention due to effect of leaching by precipitation and/or due to its utilization in other chemical or biochemical reactions. This is because aerobic decomposition may occur at and just below the landfill surface (Mc Bean et al., 1995). The concentrations at $2 \mathrm{~m}$ are significantly lower $(72 \%)$ than at other depths $(p<0.05)$. However, a positive correlation exists between the mean concentrations with increase in precipitation $\left(r=0.95 r^{2}=0.89\right)$.

Ammonia is identified as the most critical pollutant in leachate as its concentration does not change with time (Christensen et al., 1994; Christensen et al., 1999; Hartmann and Hoffmann, 1990; Krumpelbeck and Ehrig, 1999; and Robinson, 1995).However the only known mechanism for its decrease during waste decomposition is washout by precipitation (Robinson, 1995; Burton and Watson-Craik, 1998).

Similarly the concentration of TKN showed same trend as that of $\mathrm{NO}_{3}-\mathrm{N}$ and $\mathrm{NH}_{3}-\mathrm{N}$ as shown in Table 4.and Fig.4.The mean values of TKN at $0.3,2 \mathrm{~m}, 5 \mathrm{~m}$ and 60 meters were $700,211,823$ and $805 \mathrm{mg} / \mathrm{L}$ with standard error of $\pm \pm 63.1, \pm 29.30, \pm 67.5$ and \pm 62.0 respectively 
Effect of depth and age on leachate characteristics of Achan Landfill, Srinagar, Jammu and Kashmir,

Table 5. Carbonaceous pollutant concentration ..

\begin{tabular}{|c|c|c|c|c|}
\hline \multirow{2}{*}{ Parameters } & \multicolumn{4}{|c|}{ Depths } \\
\hline & $0.30 \mathrm{~m}$ & $2 \mathrm{~m}$ & $5 \mathrm{~m}$ & $60 \mathrm{~m}$ \\
\hline BOD $_{5}$ mg/L. & $\begin{array}{c}102 \\
\pm 7\end{array}$ & $\begin{array}{c}\mathbf{1 3 8} \\
+12.37\end{array}$ & $\begin{array}{c}66 \\
+5.23 \\
\end{array}$ & $\begin{array}{c}2.62 \\
+0.28\end{array}$ \\
\hline COD mg/L. & $\begin{array}{r}757 \\
+33 \\
\end{array}$ & $\begin{array}{c}1234 \\
+78 \\
\end{array}$ & $\begin{array}{r}530 \\
+39 \\
\end{array}$ & $\begin{array}{r}58 \\
+2.32\end{array}$ \\
\hline $\mathrm{BOD}_{5} / \mathrm{NH4}$ & $\begin{array}{c}0.18 \\
+0.017 \\
\end{array}$ & $\begin{array}{r}\mathbf{0 . 7 5 4} \\
+0.109 \\
\end{array}$ & $\begin{array}{c}0.094 \\
+0.0075 \\
\end{array}$ & $\begin{array}{r}0.0036 \\
+0.00048 \\
\end{array}$ \\
\hline $\mathrm{BOD}_{5} / \mathrm{COD}$ & $\begin{array}{r}0.13 \\
+0.0119\end{array}$ & $\begin{array}{c}0.111 \\
+0.00654\end{array}$ & $\begin{array}{r}\mathbf{0 . 1 2 4} \\
+0.0185 \\
\end{array}$ & $\begin{array}{c}0.04 \\
+0.00408\end{array}$ \\
\hline
\end{tabular}

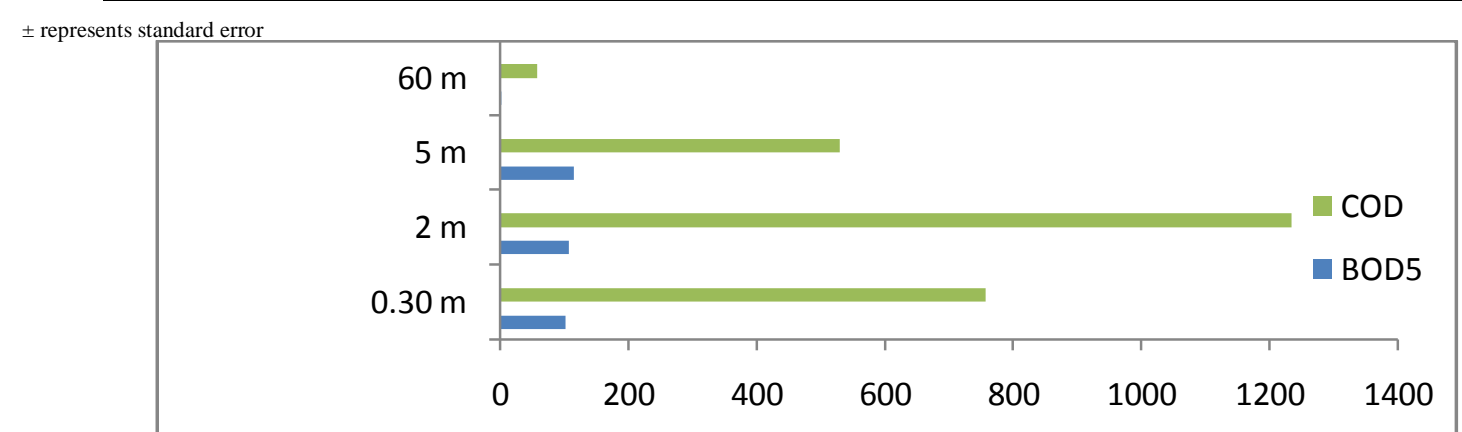

Fig.5. comparative concentration of BOD and COD at different depths

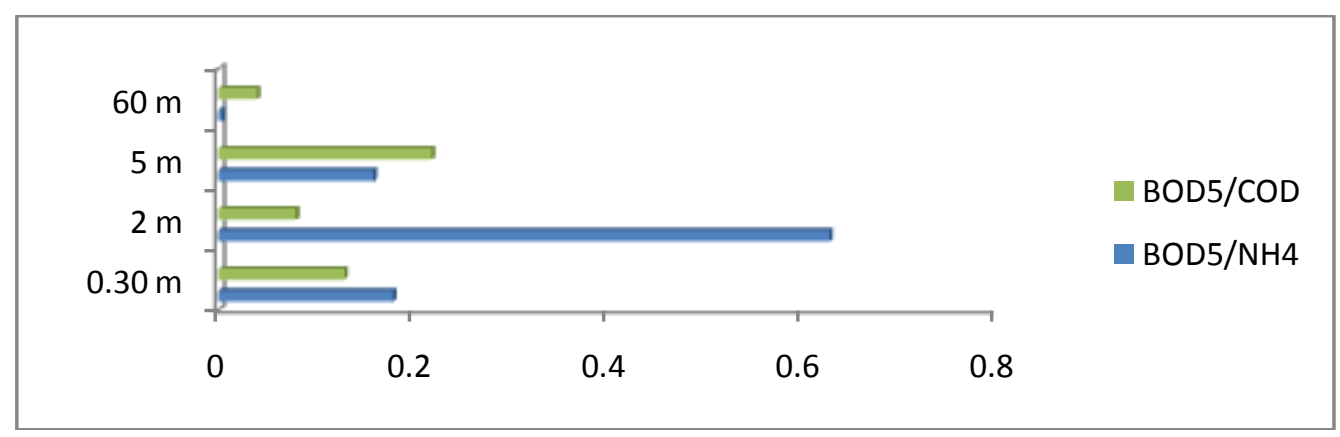

Fig.6. ratios of $\mathrm{BOD}_{5} / \mathrm{NH} 4$ and $\mathrm{BOD}_{5} / \mathrm{COD}$ at at different depths

\section{Carbonaceous pollutant}

BOD and COD are indicative of organic content in leachate and is known to decline with increasing age of landfill (Ehrig, 1989; Mc Bean et al., 1995; Akyurek, 1995; Lee et al., 2010); and Chen, 1996). Relatively lower values of BOD and COD may be attributed to the reduction of organic matter in waste and increased degradation of organic matter (Krug and Ham, 1995; and Lee et al., 2010).

The mean values of $\mathrm{BOD}_{5}$ were far lower about $1 / 40^{\text {th }}$ of the concentrations found at deeper depths (60m) compared to other depths $(\mathrm{p}<0.05)$.The mean COD values tend to show decrease with increase in depth from $1234 \mathrm{mg} / \mathrm{l}$ at $2 \mathrm{~m}$ to $58 \mathrm{mg} / \mathrm{l}$ at $60 \mathrm{~m}\left(\mathrm{r}=-0.83 ; \mathrm{r}^{2}=0.69\right)$. However, the concentrations near the surface $(0.3 \mathrm{~m})$ are about $40 \%$ lower than those observed at $2 \mathrm{~m}$ depth that shows significant differences between depths $(\mathrm{p}<0.05)$.

Significantly lower values of BOD and COD at $60 \mathrm{~m}$ depth $(97 \%$ \& $92 \%$ respectively) may be attributed to anaerobic or anoxic conditions prevalent at greater depths. Decline in BOD and COD concentrations has also been linked to washout and degradation (Reinhart and Grosh, 1998).

The ratio of $\mathrm{BOD}_{5} / \mathrm{NH}_{4}$ and $\mathrm{BOD}_{5} / \mathrm{COD}$ are an important indicator of the age and stability of a landfill and its leachate. The ratio of $\mathrm{BOD}_{5} / \mathrm{NH}_{4}$ is generally greater than 1 for younger leachates and closer to 1 or lesser for older leachates. During the studied period the mean ratio of $\mathrm{BOD}_{5} / \mathrm{NH}_{4}$ ranged between 0.002 and 1 , which implies the landfill has attained stabilization. During the study the mean ratio of $\mathrm{BOD}_{5} / \mathrm{NH}_{4}$ decreases from 0.63 at $2 \mathrm{~m}$ to 0.04 at $60 \mathrm{~m}\left(\mathrm{r}=-0.73 ; \mathrm{r}^{2}=0.53\right)$. The mean ratios at surface are less than $30 \%$ than the levels observed at $2 \mathrm{~m}$ depths $(\mathrm{p}<0.05)$.

Comparing the mean value of $\mathrm{BOD}_{5} / \mathrm{COD}$ the ratio show decrease with increase in depth over $0.3,2 \mathrm{~m}$ and $60 \mathrm{~m}\left(\mathrm{r}=-0.85 ; \mathrm{r}^{2}=0.7\right)$ while the concentration at $5 \mathrm{~m}$ depth are unusually highest nearly $81 \%$ from the concentration at $60 \mathrm{~m}(\mathrm{p}<0.05)$. The overall mean values differ significantly with respect to depth $(\mathrm{p}<0.05)$. Our results are in agreement with those of Lee et al.,(2010) and Chain and DeWallace et al., (1997) for mature 
landfills. Young and unstabilized leachate have a ratio of 0.05 or more and partially stabilized leachates have ratio 0.1 to 0.5 while old and stabilized leachates tend to have ratio less than 0.1 (Al Fadel et al., 2002).Our ratios have ranged over 0.03 to 0.29 that reflects the increasing maturity of landfill owing to metanogenesis.these results are in complete agreements with the findings of Jedrezak and Haziak, 1994.

\section{Heavy Metals}

Table 5. Heavy metal concentration at variable depths in $\mathrm{mg} / \mathrm{L}$

\begin{tabular}{|c|c|c|c|c|}
\hline \multirow{2}{*}{ Parameters } & \multicolumn{4}{|c|}{ Depths } \\
\hline & $0.30 \mathrm{~m}$ & $2 \mathrm{~m}$ & $5 \mathrm{~m}$ & $60 \mathrm{~m}$ \\
\hline $\mathbf{N i}$ & BDL & BDL & BDL & BDL \\
\hline $\mathbf{P b}$ & BDL & BDL & BDL & BDL \\
\hline $\mathrm{Cu}$ & $\begin{array}{c}\mathbf{0 . 4 5} \\
\pm 0.012\end{array}$ & $\begin{array}{c}0.22 \\
\pm 0.008\end{array}$ & BDL & BDL \\
\hline $\mathrm{Cr}$ & $\begin{array}{c}\mathbf{0 . 4 3} \\
\pm 0.009\end{array}$ & $\begin{array}{c}0.37 \\
\pm 0.011\end{array}$ & BDL & BDL \\
\hline Zn & $\begin{array}{c}\mathbf{0 . 4 8} \\
\pm 0.019\end{array}$ & $\begin{array}{c}0.29 \\
\pm 0.012\end{array}$ & BDL & BDL \\
\hline Cd & BDL & BDL & BDL & BDL \\
\hline $\mathrm{Hg}$ & BDL & BDL & BDL & BDL \\
\hline
\end{tabular}

\pm represents standard error and BDL represents below detectible limits

Heavy metal concentration at all the sites were recorded at below detectible levels except for samples collected at surface i,e 0.30 meters with concentration of $\mathrm{O} .45,0.43,0.48$ for $\mathrm{Cu}, \mathrm{Cr}$, and $\mathrm{Zn}$ with standard error of \pm 0.012 , \pm 0.009 and \pm 0.019 . The findings are in correlation to the composition of the solid waste that contains heavy metals in lesser proportions.

\section{Acknoledgements}

A special acknowledgement of appreciation goes to engineer Mr.Abid Yousuf, and Mrs.Nusrat for their generous support at landfill site during surveys and sampling.

\section{Bibliography}

[1] Abbas A. A., Jingsong G., Ping L. Z., Ying Ya P. and Al-Rekabi W. S. 2009.Review on Landfill Leachate Treatments. American Journal of Applied Sciences Vol.6(4), pp: 672-684.

[2] Akyurek, M. 1995. Trends in landfill leachate characteristics. Paper Presented at the Eighteenth international Madison Waste Conference, Department of Engineering Professional Development, Madison.

[3] Albaiges, J., Casado, F., and Ventura, F. 1986. Organic indicators of groundwater pollution by sanitary landfill. Water Res., 20, 1153.

[4] Aluko O.O., MKC Sridhar1, Oluwande P.A. 2003. Characterization of leachates from amunicipal solid waste landfill site in Ibadan, Nigeria. Journal ofEnvironmental Health Research. Vol. 2(1).

[5] Burton, S.A.Q. and Watson Craik, I.A. 1998.Ammonia and Nitrogen fluxes in landfill Sites, applicability to sustainable Landfilling. Waste Management and Research.Vol. 16, pp:41-53.

[6] Chen, P. H. 1996. Assessment of leachate from sanitary landfill: Impact of age, rainfall, and treatment. Environment International . Vol. 22( 2), pp: 225- 237.

[7] Chian, E.S.K., and DeWalle, F.B. 1977. Characterization Of Soluble Organic matter In Leachate. Environ Sci. Techol., Vol. 11(158).

[8] Christensen, T.H. and Kjeldsen, P. 1999. 'Basic biochemical processes in landfills', Chapter 2.1 in Sanitray landfilling:Process, Technology and Environmental Impact, Christensen T.H., Cossu R., and Stegmann R., Eds. Academic Press, London, UK, pp: 29.

[9] Christensen, T.H., Kjeldsen, P., Albrechtsen, H.-J., Heron, G., Nielsen, P.H., Bjerg, P.L. and Holm, P.E., Attenuation of landfill leachate pollutants in aquifers, Crit.

[10] Rev. Environ. Sci. Technol.,24, 119, 1994 Chu, L.M., Cheung, K.C. and Wong, M.H. (1994) 'Variations in the chemical properties of landfill leachate'.Journal of Environmental management. Vol. 18(1), pp: 105-109.

[11] Ehrig, H.J. 1989. Leachate Quality: In Sanitary Landfilling: Process, Technology and Environmental Impact. Edited by Christensen, H.T., Stegmann, A. \& Cossu, London: Academic Press.

[12] El-Fadel, M., Bou-Zeid, E., Chanine, W. and Alayli, B. 2003. Temporal variation of leachate quality from pre-sorted and baled municipal solid waste with high organic and moisture content. Waste Management. Vol.22(3), pp: 269-282.

[13] Esakku, S., Selvam, A. ,Palanively, K., Nagendran,R., Joseph, K. 2006. Leachate QualityOf Municipal Solid Waste Dumpsite At Chennai,India. Asian Journal of Water Pollution, environment science, resource conservation and recycling. Vol. 3(1), pp: 6976.

[14] Harmann, K.H. and Hoftmann, F. 1990. Leachate Treatment - Design Recommendations For Small But Extremely Fluctuating Highly Polluted Quantities of Water. Water Science And Technology, Vol. 22, pp: 307 - 314.

[15] Jędrczak A., Haziak K. 1994. Quantity, chemical composition and treatment of landfill leachates (In Polish). Mat. Konferencyjne IV Konferencji Szkoleniowej nt. Budowa bezpiecznych składowisk odpadów. Fundacja PUK, Poznań.

[16] Karthikeyan, O.P., Kurian, J. And Nagendran, R. 2007. Leachate Recirculation to reduce the Pollution Potential Of Waste Mined From Open Dumpsite - A Lysimeter Study. Sardinia, Eleventh International Waste Management and Landfill Symposium.

[17] Komilis, D.P., Ham, R.K. and Stegmann, R. 1999. The effect of municipal solid waste pretreatment on landfill behaviour: A literature review', Waste Management and Research, Vol. 17 (10). 
[18] Kruempelbeck, I. and Ehrig, H. J. 1997. Long-Term Behavior Of Municipal Solid Waste Landfill In Germany, In Sardinia 99. Seventh International Waste Management and Landfill Symposium, 4-8 October, S. Margherita di Pula, Cagliari, Proceedings vol. I, Christensen, T.H., Cossu, R., and Stegmann, R. Eds., CISA - Environmental Sanitary Engineeging Centre, Cagliari, Italy.

[19] Krug, M.N. and Ham, R.K., 1991. Analysis Of Long-Term Leachate Characteristics. In Proceedings Sardinia 91, Third Internationial Landfill Symposium, S. Margherita di Pula, Cagliari, Italy.

[20] Kumar, D. Khare, M. and Alappat, B.J. 2002. Threat To Ground Water Form The muncipa -al Landfills In Delhi', India. Proceedings 28th WEDC conference on sustainable environmental sanitation and water services, Kolkata, India. pp: 377-380.

[21] Lee, A.H., Nikraz, H. and Hung, Y. T. 2010. Influence of Waste Age onLandfill LeachateQuality. International Journal of Environmental Science and Development, Vol. 1(4), pp::347-350.

[22] Lu, J.C.S., Eichenberger, B. and Stearns, R.J. 1985. Leachate from municipal landfills prod -uction and management. Noyes publication, Park Ridge, NJ.

[23] McBean, E.A., Rovers, F.A. and Farquhar,G.J. 1995. Solid Waste Landfill Engineering and Design. Prentice Hall PTR, Englewood Cliffs.

[24] Qasim S.R. and ChiangW. 1994. Sanitary Landfill Leachate, Technomic Publishing Co., Inc. Lancaster.

[25] Reinhart D.R. and Grosh C.J. 1998. Analysis of Florida MSW landfill leachate quality. Florida center for solid and hazardous waste management, Report \# 97-3.

[26] Robinson, H. 2007. The Composition Of Leachates From Very Large Landfills: An International Review CWRM. Volume 8(1), pp: 19-32.

[27] Robinson, H.D. 1995. A Review of the composition of leachate from domestic waste in landfill sites. A report for the UK Department of the Environment. Reference: DE0918 A/FRI.

[28] Schultz, B. and Kjeldsen, P., Screening of organic matter in leachates from sanitary landfills using gas chromatography combined with mass spectrometry, Water Res., 20, 965, 1986.

[29] Shivakumar, D. Thandaveswara, B.S. and Chandrasekaran K.D. 2004. Solid waste Leachate Quality and Its Effects On Soil Properties. Pollution Research,Vol. 23, (1), pp: $69-81$.

[30] Stuart, M.E., and Klinck, B.A. 1998. A Catalogue Of Leachate Quality For Selected Landfills From Newly Industrialised Countries. BGS Technical Report WC/98/49

[31] Tchobanoglous, G., Theisen, H., and Eliassen, R., 1997. Solid Wastes Engineering Principles and Management Issues. McGraw Hill Book Company, New York. 